\title{
Katarzyna Kosior Łańcuch wartości dużych zbiorów danych (big data) w rolnictwie - problemy i wyzwania regulacyjne
}

\begin{abstract}
Big data value chain in agriculture - problems and regulatory challenges
The aim of the article is to take a closer look at the emerging big data value chain in agriculture and contribute to a better understanding of major regulatory problems and challenges that relate to the development and functioning of the said value chain. The analysis encompasses cases and experiences gained in the developed countries, and particularly in the EU. Currently, there are no specific regulations or public policies that would apply to big data sets and big data analytics in agriculture. The development trajectories of digital agriculture (or smart farming) are shaped primarily by provisions included in private contracts that bind farmers with agricultural technology providers. The approach to data analytics in such ecosystems is basically driven by the logic of corporate interests, which implies that lesser attention is being paid to general development needs of the sector or broader social interests. The current organization of the big data value chain basically favors the largest and the wealthiest farms. These patterns may contribute to increasing income inequalities in the sector. In the longer term, they may also harm sustainable farming systems. Although informal codes of conduct developed at industry level provide for general standards for agricultural data sharing and use, there is a need for specific regulations and policies that would support sustainable and inclusive digital transformation in agriculture. Taking into account the broader public value of aggregated agricultural data sets, such regulations and policies should particularly encourage a closer cooperation between the public and the private sector.
\end{abstract}

\begin{tabular}{|c|c|}
\hline DOI & https://doi.org/10.31268/StudiaBAS.2020.24 \\
\hline Słowa kluczowe & $\begin{array}{l}\text { cyfryzacja, rolnictwo, łańcuch wartości dużych zbiorów danych, } \\
\text { zarządzanie danymi rolniczymi, ramy regulacyjne }\end{array}$ \\
\hline Keywords & $\begin{array}{l}\text { digitalization, agriculture, big data value chain, agricultural data } \\
\text { governance, regulatory framework }\end{array}$ \\
\hline 0 autorce & $\begin{array}{l}\text { doktor nauk ekonomicznych, adiunkt w Zakładzie Ekonomiki } \\
\text { Agrobiznesu i Biogospodarki, Instytut Ekonomiki Rolnictwa } \\
\text { i Gospodarki Żywnościowej - Państwowy Instytut Badawczy • } \\
\square \text { katarzyna.kosior@ierigz.waw.pl • ORCID 0000-0003-4825-730X }\end{array}$ \\
\hline
\end{tabular}

\section{Wstęp}

Dane cyfrowe stają się nowym rodzajem czynnika produkcji, który wpływa na rozwój i konkurencyjność przedsiębiorstw, sektorów i państw ${ }^{1}$. W sektorze rolnym cyfrowa transformacja prowadzi do rozwoju systemu rolnictwa inteligentnego (smart farming), w którym decyzje dotyczące produkcji i zarządzania gospodarstwem rolnym podejmowane są na podstawie wiedzy i informacji płynących z zaawansowanych analiz danych ${ }^{2}$. Istotna część prowadzonych analiz opiera się na dużych zbiorach danych (big data), do których wykorzystuje się nowe technologie

1 OECD, Data in the digital age, "OECD Going Digital Policy Note”, Paris 2019, www.oecd.org/going-digital/ data-in-the-digital-age.pdf.

2 Takie rolnictwo opisywane jest w literaturze przedmiotu jako rolnictwo oparte na danych, rolnictwo inteligentne, rolnictwo cyfrowe, rolnictwo precyzyjne. W niniejszym opracowaniu terminy te stosowane będą zamiennie. 
i rozwiązania cyfrowe: internet rzeczy, technologię chmury obliczeniowej, algorytmy maszynowego uczenia się i sztuczną inteligencję. Wyniki badań dotyczących m.in. ziemi, roślin, pogody, zwierząt i maszyn mogą być wskazówką dla producentów rolnych co do kierunków poczynań oraz kroków, które należy podjąć, by zwiększyć wydajność, ograniczyć zużycie zasobów i poprawić rentowność działania. W rezultacie rewolucja cyfrowa ma potencjał, aby istotnie poprawić produktywność w sektorze i równocześnie zmniejszyć negatywny wpływ produkcji rolnej na środowisko naturalne ${ }^{3}$. Wiele wskazuje jednak na to, że rodzący się ekosystem rolnictwa inteligentnego - w tym jego rdzeń, czyli łańcuch wartości dużych zbiorów danych - funkcjonuje w sposób, który może ograniczać możliwości realizacji wskazanych celów.

Obecnie brak jest regulacji i polityk, które dotyczyłyby stricte dużych zbiorów danych w rolnictwie. Rolnictwo oparte na danych wciąż jest stosunkowo nowym zjawiskiem, dlatego nie ma gotowych rozwiązań regulacyjnych w tym obszarze. W rezultacie system rolnictwa cyfrowego rozwija się głównie na podstawie zapisów prywatnych umów, które wiążą rolników z wybranymi dostawcami technologii cyfrowych ${ }^{4}$. Choć na poziomie sektora przyjmowane są nieformalne kodeksy dobrych praktyk dotyczące przepływu, udostępniania i wykorzystywania danych rolniczych, zawarte w nich wytyczne ograniczają się do relacji między usługodawcami (dostawcami technologii) a usługobiorcami i właścicielami danych (rolnikami). W wielu wypadkach kodeksy te inicjowane są przez samych dostawców technologii cyfrowych dla rolnictwa. Sposoby wykorzystania danych są w takich układach determinowane logiką interesów korporacyjnych, w mniejszym zaś stopniu potrzebami rozwojowymi sektora rolnego czy szerszymi interesami społecznymi.

Jednym z głównych problemów łańcucha wartości dużych zbiorów danych w rolnictwie jest jego ograniczona przejrzystość. Ekosystem rolnictwa cyfrowego jest niezwykle rozbudowany i wciąż dynamicznie się rozwija. Pojawiają się w nim nowe podmioty, które do niedawna funkcjonowały poza sektorem rolno-spożywczym ${ }^{5}$. Liczne możliwości monetyzowania danych cyfrowych (tj. uzyskiwania korzyści ekonomicznych z tytułu posiadanych zasobów danych) sprawiają, że rolnicy mają wątpliwości dotyczące przekazywania danych ze swoich gospodarstw rolnych dostawcom rozwiązań cyfrowych. Podnoszone obawy dotyczą m.in. braku kontroli nad przepływem danych w łańcuchu, problemu potencjalnych naruszeń prawa do prywatności, możliwych dodatkowych oraz nieujawnianych celów analiz danych czy nieuczciwego podziału korzyści wynikających z wykorzystania danych ${ }^{6}$. Dodatkową słabością jest koncentracja łańcucha wartości dużych zbiorów danych w systemie rolnictwa cyfrowego na danych pochodzących z wybranych typów i rodzajów gospodarstw rolnych. Są to zazwyczaj duże i dobrze sytuowane

3 S. Sonka, Big Data: Fueling the Next Evolution of Agricultural Innovation, "Journal of Innovation Management" 2016, t. 4, nr 1, s. 130, https://doi.org/10.24840/2183-0606_004.001_0008.

4 L. Wiseman J. Sanderson, A. Zhang, E. Jakku, Farmers and their data: An examination of farmers' reluctance to share their data through the lens of the laws impacting smart farming, "NJAS - Wageningen Journal of Life Sciences" 2019, t. 90-91, s. 2, https://doi.org/10.1016/j.njas.2019.04.007.

5 S. Wolfert, L. Ge, C. Verdouw, M.J. Bogaardt, Big Data in Smart Farming - A review „Agricultural Systems” 2017, t. 153, s. 75-76, https://doi.org/10.1016/j.agsy.2017.01.023.

6 L. Wiseman, J. Sanderson, A. Zhang, E. Jakku, op. cit., s. 7. 
gospodarstwa, które posiadają dostęp do nowoczesnych maszyn i urządzeń rolniczych ${ }^{7}$. Można więc zastanawiać się, czy tak okrojony system rolnictwa cyfrowego nie doprowadzi do nowych podziałów i nierówności w sektorze i na obszarach wiejskich.

Jeżeli wziąć pod uwagę transformacyjny wpływ cyfryzacji i zaawansowanych analiz danych na produkcję rolną i rozwój gospodarstw rolnych w kolejnych dekadach, badanie struktury i mechanizmów funkcjonowania łańcucha wartości dużych zbiorów danych w rolnictwie wydaje się szczególnie istotne. Choć cyfryzacja jest obecna w rolnictwie od wielu lat, wiedza na temat jej dynamiki i kierunków oddziaływania jest wciąż ograniczona. Identyfikacja podmiotów zaangażowanych w ekosystem rolnictwa cyfrowego oraz ocena ich roli w procesach gromadzenia, przechowywania i wykorzystywania danych rolniczych mogą pomóc w zrozumieniu cyfrowej transformacji w sektorze. Równie istotna jest odpowiedź na pytanie, czy dzisiejsze rozwiązania regulacyjne i sektorowe dotyczące zarządzania danymi rolniczymi pozwalają na pełną realizację potencjału cyfrowej rewolucji w zgodzie z zasadami zrównoważonego oraz inkluzywnego rozwoju sektora rolnego i obszarów wiejskich.

Celem artykułu jest zatem zaprezentowanie łańcucha big data w sektorze rolnym oraz omówienie głównych problemów i wyzwań regulacyjnych, jakie wiążą się z jego funkcjonowaniem. Tekst opiera się na przeglądzie literatury przedmiotu oraz na analizie dokumentów, aktów prawnych i materiałów źródłowych, które dotyczą ekosystemu rolnictwa cyfrowego oraz wyłaniającego się łańcucha wartości dużych zbiorów danych w rolnictwie krajów rozwiniętych. W pierwszej części artykułu przedstawiono koncepcję łańcucha wartości dużych zbiorów danych. Wskazano strukturę łańcucha, mechanizmy jego działania oraz znaczenie przepływów informacji i danych w łańcuchu dla określania kierunków i tempa cyfrowych zmian w gospodarce. Ekosystem rolnictwa cyfrowego oraz problemy i wyzwania związane z gromadzeniem, przetwarzaniem, analizowaniem i wykorzystywaniem danych cyfrowych w sektorze rolnym omówiono w drugiej części opracowania. Trzecią i ostatnią jego część poświęcono zagadnieniom regulacyjnym. Zaprezentowano obecne podejścia do regulacji problemów rozwoju rolnictwa cyfrowego - nieformalne kodeksy dobrych praktyk dotyczące udostępniania i przepływu danych rolniczych oraz zarządzania tymi danymi, a także akty prawne i inicjatywy, które mają bądź mogą mieć wpływ na funkcjonowanie łańcucha wartości dużych zbiorów danych w rolnictwie. Szczególną uwagę skupiono na regulacjach i rozwiązaniach prawnych przyjmowanych na szczeblu Unii Europejskiej.

\section{Łańcuch wartości dużych zbiorów danych - istota i znaczenie w dobie cyfrowych zmian}

Duże zbiory danych są jedną z głównych sił napędowych gospodarki cyfrowej ${ }^{8}$. Choć nie ma oficjalnie przyjętej definicji dużych zbiorów danych, terminem tym określa się najczęściej szybko przyrastające zasoby danych cyfrowych, opisujące procesy, zdarzenia i zjawiska zachodzące

7 I.M. Carbonell, The ethics of big data in big agriculture, „Internet Policy Review" 2016, t. 5, nr 1, s. 3-4, http:// doi.org/10.14763/2016.1.405.

8 OECD, Vectors of Digital Transformation, "OECD Digital Economy Papers” 2019, nr 273, OECD Publishing, Paris, s. 7, https://doi.org/10.1787/5ade2bba-en. 
zarówno w świecie fizycznym, jak i w świecie wirtualnym ${ }^{9}$ Mogą to być dane dotyczące przyrody (np. pogody, ziemi, roślin, zwierząt), maszyn (sprzętu, pojazdów, innych urządzeń) i ludzi (m.in. decyzji i zwyczajów zakupowych konsumentów, aktywności użytkowników w mediach społecznościowych i innych platformach internetowych). Wskazuje się na trzy główne cechy big data (3V) - ich wielkość i masowy charakter (volume), różnorodność (variety) oraz prędkość (velocity), z jaką się pojawiają. W rozszerzonych opisach i definicjach zjawiska podkreśla się również wartość (value) wielkich zbiorów danych, potrzebę zapewnienia wiarygodności danych (veracity) i ich wizualizowania (visualization) ${ }^{10}$.

Ekspansja internetu rzeczy oraz zwiększająca się popularność platform internetowych przekładają się na bardzo wysoką dynamikę przyrostu danych (średnio ponad 200\% rocznie w ciągu ostatnich pięciu lat). Zgodnie z szacunkami w 2020 r. ilość informacji i danych cyfrowych, stanowiących potencjalny wsad do analiz big data, wyniesie ponad 25 zetabajtów. W 2025 r. wolumen ten wzrośnie do rekordowego poziomu 175 zetabajtów ${ }^{11}$. Nowe technologie obliczeniowe i programy komputerowe wspierane sztuczną inteligencją pozwalają wydobywać ze zgromadzonych zasobów danych wiedzę, informacje i praktyczne spostrzeżenia, które można wykorzystać do optymalizowania działań i procesów w różnych obszarach i dziedzinach życia. Dane cyfrowe stają się więc nowym rodzajem kapitału, który decyduje o uzyskiwaniu przewagi konkurencyjnej oraz o możliwościach rozwoju przedsiębiorstw i organizacji ${ }^{12}$. W rezultacie w ostatnich latach w różnych sektorach i branżach wzrosło zainteresowanie pozyskiwaniem i monetyzowaniem danych cyfrowych. Przedsiębiorstwa realizujące strategię cyfrowej transformacji włączają do systemów zarządzania analizy dużych zbiorów danych. Równocześnie rośnie liczba organizacji, które swoje modele biznesowe w całości opierają na wykorzystaniu danych cyfrowych ${ }^{13}$.

Opis i wyjaśnianie procesów i działań związanych z pozyskiwaniem i wykorzystywaniem danych cyfrowych w różnych obszarach i sektorach życia społeczno-gospodarczego umożliwia koncepcja łańcucha wartości dużych zbiorów danych (big data value chain). Koncepcja ta opisuje przepływ informacji w ramach systemu wielkich zbiorów danych jako kolejne kroki prowadzące do tworzenia wartości oraz pozyskiwania przydatnych spostrzeżeń z danych ${ }^{14}$. Przetwarzanie i inne operacje na danych są niezbędne, ponieważ same surowe dane cyfrowe nie mają większej

9 Przegląd definicji terminu big data znaleźć można m.in. w: M. Tabakow, J. Korczak, B. Franczyk, Big Data definicje, wyzwania i technologie informatyczne, „Informatyka Ekonomiczna” 2014, nr 1(31), s. 141.

10 E. Isitor, C. Stanier, Defining Big Data [w:] Proceedings of the International Conference on Big Data and Advanced Wireless Technologies. BDAW 2016, New York 2016, s. 1-6.

11 Volume of data/information created worldwide from 2010 to 2024 (in zettabytes), Statista, https://www.statista. com/statistics/871513/worldwide-data-created/ [dostęp: 15 maja 2020 r.].

12 J. Sadowski, When data is capital: Datafication, accumulation, and extraction, „Big Data \& Society” 2019, t. 6, nr 1, s. 3, https://doi.org/10.1177/2053951718820549.

13 G. Micheletti, C. Pepato, Second Interim Report: The European Data Market Monitoring Tool: Key Facts \& Figures, First Policy Conclusions, Data Landscape and Quantified Stories, 28 June 2019, s. 13, http://datalandscape.eu/ sites/default/files/report/D2.6_EDM_Second_Interim_Report_28.06.2019.pdf.

14 E. Curry, The Big Data Value Chain: Definitions, Concepts, and Theoretical Approaches [w:] New Horizons for a Data-Driven Economy. A Roadmap for Usage and Exploitation of Big Data in Europe, red. J.M. Cavanillas, E. Curry, W. Wahlster, Springer, Cham 2016, s. 31. 
wartości ekonomicznej. Funkcjonowanie łańcucha jest możliwe dzięki współpracy jednostek i organizacji, które wspólnie tworzą ekosystem big data. Kontekst biznesowy i relacje między podmiotami tworzącymi ekosystem big data różnią się w zależności od sektora i branży.

Łańcuch wartości dużych zbiorów danych składa się z serii czynności, które następują po sobie w określonym porządku. Właściwa organizacja i odpowiedni przebieg czynności pozwalają tworzyć wartość dla organizacji i przedsiębiorstw. W ogólnym modelu łańcucha wartości danych wyróżnia się cztery podstawowe elementy (ogniwa): a) generowanie danych, b) zbieranie danych, c) analizę danych oraz d) wykorzystanie danych. Ze względu na złożony charakter dużych zbiorów danych większość badaczy uzupełnia wskazany model o dodatkowe czynności. Edward Curry wymienia pięć elementów łańcucha wartości dużych zbiorów danych: pozyskiwanie danych, analizę danych, zapewnianie jakości i przydatności utrzymywanych repozytoriów danych, przechowywanie danych oraz wykorzystanie danych ${ }^{15}$. Abou Zakaria Faroukhi i współpracownicy wyróżniają siedem elementów - ogniw łańcucha: generowanie danych, pozyskiwanie danych, wstępne przetwarzanie danych, przechowywanie danych, analizę danych, wizualizację danych oraz wykorzystanie danych (rysunek 1$)^{16}$.

\section{Rysunek 1. Łańcuch wartości dużych zbiorów danych}

\begin{tabular}{|c|c|c|c|c|c|c|}
\hline $\begin{array}{c}\text { generowanie } \\
\text { danych }\end{array}$ & $\begin{array}{c}\text { pozyskiwanie } \\
\text { danych }\end{array}$ & $\begin{array}{l}\text { wstępne prze- } \\
\text { twarzanie } \\
\text { danych }\end{array}$ & $\begin{array}{l}\text { przechowywa- } \\
\text { nie danych }\end{array}$ & $\begin{array}{l}\text { analiza } \\
\text { danych }\end{array}$ & $\begin{array}{c}\text { wizualizacja } \\
\text { danych }\end{array}$ & $\begin{array}{l}\text { wykorzysta- } \\
\text { nie danych }\end{array}$ \\
\hline $\begin{array}{l}\text { - dane ustruk- } \\
\text { turyzowane, } \\
\text { na wpół } \\
\text { ustruktu- } \\
\text { ryzowane, } \\
\text { nieustruktu- } \\
\text { ryzowane } \\
\text { - aplikacje, } \\
\text { ERP, media }\end{array}$ & $\begin{array}{l}\text { - wsadowe } \\
\text { ładowanie } \\
\text { danych } \\
\text { - strumie- } \\
\text { niowe } \\
\text { ładowanie } \\
\text { danych } \\
\text { - mikro- } \\
\text { wsadowe } \\
\text { ładowanie } \\
\text { danych }\end{array}$ & $\begin{array}{l}\text { - czyszczenie } \\
\text { - redukowanie } \\
\text { - przekształ- } \\
\text { canie } \\
\text { - dyskretyzacja }\end{array}$ & $\begin{array}{l}\text { - modele } \\
\text { przechowy- } \\
\text { wania } \\
\text { - modele } \\
\text { danych } \\
\text { - rozproszony } \\
\text { system } \\
\text { przechowy- } \\
\text { wania }\end{array}$ & $\begin{array}{l}\text { - analityka } \\
\text { predykcyjna } \\
\text { - analityka de- } \\
\text { skryptywna } \\
\text { - analityka } \\
\text { preskryp- } \\
\text { tywna } \\
\text { - analizy diag- } \\
\text { nostyczne }\end{array}$ & $\begin{array}{l}\text { - wizualizacja } \\
\text { - monitoring } \\
\text { - diagramy } \\
\text { - mapy } \\
\text { - modele 3D }\end{array}$ & $\begin{array}{l}\text { - monetyzacja } \\
\text { w ramach } \\
\text { organiza- } \\
\text { cji - użytek } \\
\text { wewnętrzny } \\
\text { - monetyzacja } \\
\text { poprzez } \\
\text { działania } \\
\text { zewnętrzne }\end{array}$ \\
\hline
\end{tabular}

Źródło: Opracowanie własne na podstawie: A.Z. Faroukhi, I. El Alaoui, Y. Gahi, A. Amine, Big data monetization throughout Big Data Value Chain: a comprehensive review, IJJournal of Big Data" 2020, 7:3, https://doi.org/10.1186/ s40537-019-0281-5, s. 8.

W każdym z ogniw łańcucha wartości dużych zbiorów danych realizowany jest określony zestaw czynności. Pierwsze ogniwo jest związane z generowaniem danych cyfrowych. Rozwój technologii informacyjno-komunikacyjnych oraz coraz lepszy dostęp do internetu sprawiają, że dane cyfrowe - osobowe i nieosobowe - są obecnie generowane bardzo szybko. Równocześnie jednak tempo przyrostu danych pozostaje zróżnicowane na poziomie poszczególnych sektorów, branż, grup podmiotów i przedsiębiorstw. W sektorach tradycyjnych (np. budownictwie, górnictwie, rolnictwie), w których wykorzystanie nowych technologii, aplikacji mobilnych i maszyn wzbogaconych o rozwiązania cyfrowe (np. czujniki) jest generalnie niższe

15 Ibidem, s. 32

16 A.Z. Faroukhi, I. El Alaoui, Y. Gahi, A. Amine, Big data monetization throughout Big Data Value Chain: a comprehensive review, ,Journal of Big Data" 2020, 7:3, s. 8, https://doi.org/10.1186/s40537-019-0281-5. 
niż w sektorach, w których większość działań i transakcji realizowana jest w internecie lub w internecie rzeczy (np. w sektorze bankowym, e-commerce, mediach), dostęp do niektórych rodzajów danych może być utrudniony. Zarazem wygenerowane dane mogą dotyczyć tylko wybranych typów podmiotów bądź rodzajów aktywności. W takich przypadkach możliwości monetyzowania danych w łańcuchu wartości mogą być ograniczone. Gorszy dostęp do danych może też skutkować utrudnieniem pojawienia się efektywnie działającego łańcucha wartości dużych zbiorów danych.

Wyspecjalizowane i złożone czynności podejmowane w kolejnych etapach łańcucha - od pozyskiwania danych, poprzez ich przetwarzanie i przechowywanie, na analizach i wizualizacjach skończywszy - wymagają sporych nakładów finansowych i organizacyjnych. Wymagają również dostępu do specjalistycznego oprogramowania, pracowników przygotowanych do pracy z danymi i ekspertów posiadających wiedzę dziedzinową z obszarów, w których wyniki analiz mają być wykorzystane. Przedsiębiorstwa uwzględniają koszty ponoszone w kolejnych etapach łańcucha wartości danych w cenie oferowanych produktów i usług opartych na danych ${ }^{17}$. Mogą też poszukiwać innych dróg monetyzowania danych. Monetyzacja danych może mieć bowiem charakter zarówno wewnętrzny - następuje wówczas w oparciu o działania skoncentrowane na wykorzystaniu posiadanych zasobów danych do osiągnięcia większej wydajności w ramach przedsiębiorstwa (np. do uzyskania lepszych wyników produkcji przy mniejszych nakładach), jak i zewnętrzny. W tym drugim przypadku przedsiębiorstwa dążą do pozyskania źródeł dochodów poprzez lepsze rozpoznanie potrzeb konsumentów, dostęp do informacji istotnych z punktu widzenia rozwoju nowych produktów i usług, uruchamianie platform oferujących usługi analityczne, tworzenie konsorcjów danych i partnerstw z podmiotami trzecimi, a także sprzedaż zagregowanych i zanonimizowanych danych ${ }^{18}$.

Stosunkowo rozległe możliwości tworzenia wartości z danych cyfrowych skłaniają przedsiębiorstwa do angażowania się w projekty big data. Dane cyfrowe są pozbawione wielu ograniczeń, które są charakterystyczne dla zasobów materialnych. Można je multiplikować, transferować i zapisywać na różnych urządzeniach. Dzięki temu wiele podmiotów może mieć do nich dostęp w tym samym czasie niezależnie od lokalizacji. Co kluczowe, te same dane cyfrowe mogą być wykorzystywane wielokrotnie do różnych celów. Nawet jeśli określone zasoby danych stracą swoją pierwotną wartość, nieustanny przyrost danych powoduje, że pojawiają się nowe możliwości generowania zysków ze zgromadzonych danych. Z tego względu rośnie zainteresowanie akumulowaniem zasobów danych cyfrowych. Potencjalne korzyści wynikające z posiadania dostępu do danych oraz z łączenia różnych baz sprawiają, że procesy gromadzenia i pozyskiwania danych bardzo często wychodzą poza sektorowe czy branżowe podziały w gospodarce. Modele biznesowe wielu nowych przedsiębiorstw i startupów w całości opierają się na danych cyfrowych i działalności w jednym lub w kilku ogniwach łańcucha wartości big data. Również duża liczba funkcjonujących już przedsiębiorstw produkcyjnych, w tym dostawców urządzeń

17 W. Kerber, Data-sharing in IoT ecosystems from a competition law perspective: The example of connected cars, "MAGKS Joint Discussion Paper Series in Economics" 2019, nr 21, s. 5.

18 R. Moro Visconti, A. Larocca, M. Marconi, Big Data-Driven Value Chains and Digital Platforms: From Value Co-Creation to Monetization, 2017, s. 16-17, http://dx.doi.org/10.2139/ssrn.2903799. 
i maszyn wzbogacanych o rozwiązania cyfrowe, uzupełnia swoje strategie rozwoju o działania związane z analityką big data.

Niektóre przedsiębiorstwa opierające swoją działalność na technologiach informacyjno-komunikacyjnych i cyfrowych stosunkowo szybko mogą uzyskać pozycję dominującą na rynku danych. Do koncentracji danych w ręku pojedynczych podmiotów prowadzą zarówno szybko osiągane korzyści skali i zakresu w internecie, jak i efekty sieciowe (network effects). Brak rywalizacji w konsumpcji produktów i usług cyfrowych oznacza, że przedsiębiorstwa, które je oferują, mogą w krótkim czasie osiągać ogromne korzyści skali. Produkty i usługi cyfrowe są bowiem powielane po niskich lub zerowych kosztach krańcowych. Do rosnącego znaczenia pojedynczych podmiotów w łańcuchu wartości dużych zbiorów danych przyczyniają się także użytkownicy produktów i usług cyfrowych: konsumenci decydują się najczęściej na te produkty i usługi cyfrowe (platformy internetowe), z których korzysta większa liczba osób. Im szersza sieć użytkowników platformy, tym większa jej wartość i przydatność dla nowych użytkowników. Rozrastająca się sieć użytkowników może doprowadzić do uzyskania krytycznej masy danych w ramach jednej platformy, która de facto wyeliminuje konkurencję z danego rynku lub z wielu rynków.

Dużą ilością danych cyfrowych (osobowych i nieosobowych) dysponuje również sektor publiczny. Projekty publiczne oparte na wykorzystaniu dużych zbiorów danych dotyczą różnych tematów i obszarów życia społeczno-gospodarczego ${ }^{19}$. Czynności i procesy w łańcuchu wartości dużych zbiorów danych sektora publicznego nie różnią się zasadniczo od czynności podejmowanych w łańcuchu z udziałem przedsiębiorstw prywatnych. Cele wykorzystania danych są jednak inne - podczas gdy monetyzacja danych w sektorze prywatnym ma służyć podnoszeniu wydajności procesów i maksymalizacji zysków, projekty big data sektora publicznego z założenia nie mają komercyjnego charakteru. Skierowane są na podniesienie jakości życia obywateli, poprawę działania polityk publicznych, wzrost dobrobytu społecznego i inne cele społeczne ${ }^{20}$. Równocześnie część danych sektora publicznego udostępniana jest obywatelom i przedsiębiorstwom w odpowiednich formatach jako dane otwarte ${ }^{21}$. Otwieranie danych publicznych pozytywnie wpływa na funkcjonowanie łańcucha wartości dużych zbiorów danych: zwiększa przepływ informacji w łańcuchu, rozszerza możliwości analizy oraz przyspiesza rozwój innowacyjnych produktów i usług cyfrowych ${ }^{22}$. Skądinąd, z różnych powodów, w tym też ze względu na reżim praw własności, przepływ danych cyfrowych w drugą stronę, tj. z sektora prywatnego do sektora publicznego, jest obecnie niewielki lub znikomy. Ograniczenia te sprawiają, że w wielu istotnych dla obywateli obszarach sektor publiczny nie jest w stanie realizować efektywnych projektów big data.

19 R. Munné, Big Data in the Public Sector [w:] New Horizons for a Data-Driven Economy. A Roadmap for Usage and Exploitation of Big Data in Europe, red. J.M. Cavanillas, E. Curry, W. Wahlster, Springer, Cham 2016, s. 198-200.

20 K. Kosior, Big data w sektorze publicznym - szanse, ograniczenia, perspektywy , „Kultura i Polityka” 2016, nr 20, s. 23-25.

21 R. Munné, op. cit., s. 199.

22 OECD, Enhancing Access to and Sharing of Data: Reconciling Risks and Benefits for Data Re-use across Societies, OECD Publishing, Paris 2019, s. 117, https://doi.org/10.1787/276aaca8-en. 


\section{Problemy i wyzwania związane z rozwojem rolnictwa cyfrowego}

Cyfrowa transformacja w rolnictwie przebiega generalnie wolniej niż w innych sektorach gospodarki ${ }^{23}$. Szerszym cyfrowym zmianom nie sprzyja obecna organizacja łańcucha wartości dużych zbiorów danych w rolnictwie. Procesy gromadzenia, przetwarzania i wykorzystywania danych rolniczych zachodzą w złożonych i mało przejrzystych ekosystemach cyfrowych. W rezultacie poważnym problemem w systemach rolnictwa inteligentnego/cyfrowego jest niewielkie zaufanie rolników do dostawców technologii i usług cyfrowych dla rolnictwa ${ }^{24}$. Negatywnym zjawiskiem są również procesy akumulacji danych rolniczych w rękach pojedynczych podmiotów, które utrudniają rolnikom zmianę dostawców produktów i usług cyfrowych. Problemem jest też okrojona oferta produktów i usług dla rolnictwa cyfrowego - koncentruje się ona głównie na grupie największych i najzamożniejszych gospodarstw rolnych. Dominacja interesów korporacyjnych w łańcuchu wartości dużych zbiorów danych rolniczych oznacza, że potencjał związany z cyfrową rewolucją nie jest obecnie w pełni wykorzystywany. W kolejnych sekcjach zostaną szerzej omówione wskazane problemy i wyzwania, w szczególności:

- złożony charakter umów łączących dostawców technologii cyfrowych z rolnikami;

- niejasne prawa własności do danych rolniczych;

- zagrożenia prawa do prywatności i bezpieczeństwa danych;

- koncentracja danych ograniczająca konkurencję na rynku produktów i usług cyfrowych dla rolnictwa;

- nierówny poziom danetyzacji gospodarstw rolnych;

- straty społeczne związane z niewystarczającą współpracą sektora prywatnego i sektora publicznego w łańcuchu wartości dużych zbiorów danych rolniczych.

\section{Złożony charakter umów określających warunki gromadzenia i wykorzystywania danych rolniczych}

Zasady i warunki gromadzenia, przetwarzania, udostępniania i wykorzystywania danych z gospodarstw rolnych określane są w umowach i kontraktach, które rolnicy podpisują z dostawcami technologii cyfrowych, producentami maszyn i urządzeń rolniczych wyposażonych w systemy pozyskiwania i rejestrowania danych, producentami nawozów, środków agrochemicznych i środków do produkcji zwierzęcej, a także z podmiotami świadczącymi usługi cyfrowe i dorad$\mathrm{cze}^{25}$. Maszyny i inne środki produkcji dla rolnictwa są coraz częściej sprzedawane w pakietach obejmujących płatny oraz odnawialny dostęp do platform online i aplikacji mobilnych wspie-

23 F. Calvino, Ch. Criscuolo, L. Marcolin, M. Squicciarini, A taxonomy of digital intensive sectors, „OECD Science, Technology and Industry Working Papers" 2018, nr 14, OECD Publishing, Paris 2018, s. 27.

24 E. Jakku et al., "If they don't tell us what they do with it, why would we trust them?" Trust, transparency and benefit-sharing in Smart Farming, „NJAS - Wageningen Journal of Life Sciences" 2019, t. 90-91, s. 8, https:// doi.org/10.1016/j.njas.2018.11.002.

25 L. Wiseman, J. Sanderson, A. Zhang, E. Jakku, op. cit., s. 7. 
rających proces podejmowania decyzji w gospodarstwie ${ }^{26}$. Dzięki temu rolnicy mogą korzystać z rekomendacji dotyczących produkcji i zarządzania gospodarstwem rolnym, które uwzględniają wyniki analiz danych z ich gospodarstw, jak i dodatkowe dane i czynniki.

Dostęp do platformy i powiązanych usług wymaga podpisania umowy, w której rolnik zgadza się na gromadzenie i przetwarzanie danych z gospodarstwa. Najczęściej wykorzystywanymi formami umów są umowy subskrypcyjne i licencje użytkownika końcowego. Umowy te określa się też mianem „umowy gotowce”, ponieważ przedkładane są w takim samym brzmieniu wszystkim potencjalnym użytkownikom ${ }^{27}$. Mają więc de facto charakter jednostronny - rolnicy nie mogą negocjować ani zmieniać ich zapisów. Uzyskanie dostępu do danej usługi czy produktu wymaga zgody na wszystkie warunki umowy. Najczęściej umowy te widoczne są dla rolnika dopiero w momencie pobierania aplikacji, rejestracji na platformie bądź po pierwszym uruchomieniu maszyny z oprogramowaniem. Do umów licencyjnych załączane są linki, które prowadzą do dodatkowych dokumentów opisujących politykę prywatności stosowaną przez danego dostawcę. W wielu przypadkach zasady gromadzenia, wykorzystywania i udostępniania danych opisywane są raczej w dokumentach z polityką prywatności niż w samych licencjach użytkownika ${ }^{28}$.

Zarówno umowy licencyjne, jak i polityka prywatności są dokumentami, które zawierają zapisy złożone oraz trudne do zrozumienia dla przeciętnego odbiorcy. Są to też umowy stosunkowo długie. Dokładne zapoznanie się z nimi wymaga więc nie tylko znajomości trudnych terminów prawniczych, lecz także czasu. Badania pokazują, że rolnicy bardzo często nie czytają treści podpisywanych umów i dokumentów, które im towarzyszą. Sprzyjają temu również ikony zgody, które pozwalają na automatyczne podpisanie umowy po jednym kliknięciu ${ }^{29}$. W rezultacie rolnicy nie wiedzą dokładnie, na jakie warunki zarządzania danymi się godzą. Równocześnie duża grupa rolników nie ma dostępu do profesjonalnego doradztwa w tym obszarze. Problemy związane z zarządzaniem danymi cyfrowymi w systemach rolnictwa inteligentnego są wciąż nowym tematem dla wielu doradców rolniczych.

\section{Problem praw własności do danych rolniczych}

Dane rolnicze produkowane są w złożonym ekosystemie współpracujących ze sobą jednostek, przedsiębiorstw i organizacji ${ }^{30}$. Ich produkcja wymaga zaangażowania rolników, producentów maszyn, urządzeń rolniczych i innych środków produkcji dla rolnictwa z jednej strony oraz spółek technologicznych zajmujących się łącznością, produkcją sprzętu i oprogramowania komputerowego z drugiej. Konieczne są również zaangażowanie i wsparcie jednostek sektora publicznego,

26 Precisionfarming. Trends and Outlook, AGRI MECH, June 2018, http://online.fliphtml5.com/zrio/dzoa/\#p=6 [dostęp: 27 maja 2020 r.].

27 L. Wiseman, J. Sanderson, A. Zhang, E. Jakku, op. cit., s. 7.

28 Ibidem.

29 M.E. Sykuta, Big Data in Agriculture: Property Rights, Privacy and Competition in Ag Data Services, „International Food and Agribusiness Management Review" 2016, t. 19A (1030-2016-83141), s. 67.

30 S. Wolfert, L. Ge, C. Verdouw, M.J. Bogaardt, op. cit., s. 75. 
które odpowiadają za utrzymanie dostępu do danych satelitarnych i innych danych pozwalających na monitorowanie warunków przyrodniczych i pozaprzyrodniczych wpływających na działalność rolniczą. Każdy z wymienionych podmiotów ma określony wkład w wygenerowane dane rolnicze ${ }^{31}$. Trudno zatem wskazać podmiot, który miałby wyłączne prawa własności do szeroko ujmowanych danych rolnictwa inteligentnego ${ }^{32}$. Przy tym dane wygenerowane na obszarze danego gospodarstwa są bezpośrednim efektem pracy rolnika. Dotyczą one ziemi i zwierząt, które są własnością rolnika. Wytwarzane są za pośrednictwem sprzętu i maszyn, które zostały przez rolnika zakupione bądź wyleasingowane. Przyjmuje się więc, że ta część danych rolniczych, która dotyczy bezpośrednio gospodarstwa oraz procesów, które w nim zachodzą, pozostaje własnością rolnika.

W umowach, które rolnicy podpisują z producentami maszyn i dostawcami technologii cyfrowych, można znaleźć odrębne zapisy wskazujące, że rolnicy pozostają właścicielami danych zebranych na obszarze ich gospodarstw ${ }^{33}$. Prawa te obejmują jednak zasadniczo tylko tzw. surowe dane (raw data), tj. dane, które nie zostały przetworzone czy przygotowane do właściwych analiz. Równocześnie dostawcy technologii rolniczych zazwyczaj zastrzegają w umowach, że mają prawo decydować o sposobach wykorzystania danych przetworzonych oraz zagregowanych z danymi z innych gospodarstw rolnych bądź z innych źródeł. Oznacza to, że po przetworzeniu danych oraz ich włączeniu do zagregowanych baz danych dane takie przestają być de facto własnością rolników, a stają się własnością dostawców technologii rolniczych i cyfrowych.

W różnych systemach prawnych, w tym w prawie UE, prawa własności podmiotów agregujących dane wynikają z ochrony praw własności intelektualnej. Uzasadnieniem nabycia praw są wysokie koszty i nakłady, jakie podmioty agregujące dane ponoszą przy tworzeniu i utrzymywaniu nowych baz danych ${ }^{34}$. Pojawiają się jednak wątpliwości, czy obecne uregulowania prawne i praktyki zapewniają sprawiedliwy podział korzyści w ramach łańcucha wartości dużych zbiorów danych ${ }^{35}$. Cyfryzacja przyspieszyła bowiem znacznie produkcję danych oraz ułatwiła procesy ich gromadzenia i agregowania. Otwarła jednocześnie przed przedsiębiorstwami nowe możliwości biznesowego i komercyjnego wykorzystania danych. Wielu rolników obawia się w związku z tym, że ich dane będą wykorzystywane do celów, które nie są otwarcie deklarowane w podpisywanych umowach, a w szczególności tego, że dostawcy środków produkcji - mając dostęp do danych na temat produkcji, ziemi i zwierząt w gospodarstwie - mogą narzucać nadmiernie wygórowane ceny bądź stosować inne niekorzystne dla rolników praktyki handlowe ${ }^{36}$. W tym

31 R. Darnell et al., The Current and Future State of Australian Agricultural Data, „Farm Policy Journal” 2018, t. 15, nr 1, s. 45.

32 N. Duch-Brown, B. Martens, F. Mueller-Langer, The economics of ownership, access and trade in digital data, „JRC Working Papers on Digital Economy" 2017-01, s. 33; F. van Schalkwyk, A. Andrason, G. Magalhaes, A New Harvest: A Review of the Literature on Data Ownership Focusing on the Agricultural Sector, 29 October 2018, s. 4, http://dx.doi.org/10.2139/ssrn.3379530.

33 M.E. Sykuta, op. cit., s. 68-69.

34 L. Wiseman, J. Sanderson, A. Zhang, E. Jakku, op. cit., s. 8.

35 Zob. B. Prainsack, Logged out: Ownership, exclusion and public value in the digital data and information commons, „Big Data \& Society” 2019, t. 6, nr 1, s. 2, https://doi.org/10.1177/2053951719829773.

36 M.E. Sykuta, op. cit., s. 65. 
kontekście możliwość zachowania kontroli nad przepływem i wykorzystaniem danych zagregowanych w łańcuchu wartości może być dla rolników istotniejsza niż zapisywane w umowach formalne prawa własności do danych surowych ${ }^{37}$.

\section{Zagrożenia prawa do prywatności i bezpieczeństwa danych}

Swobodny przepływ danych sprzyja innowacjom oraz zwiększa konkurencję między podmiotami, które dostarczają produkty i usługi cyfrowe. Równocześnie jednak może prowadzić do sytuacji, w których prawa do prywatności właścicieli danych oraz bezpieczeństwo danych nie są dostatecznie chronione ${ }^{38}$. W momencie podpisywania umowy oraz udzielania zgód na przetwarzanie danych rolnik zazwyczaj nie wie, z jakimi podmiotami przedsiębiorstwo gromadzące jego dane będzie współpracować w przyszłości. Na przepływ danych mogą wpływać fuzje i przejęcia przedsiębiorstw, a także nowe umowy o partnerstwie i współpracy z podmiotami, które nie były wymieniane w umowach podpisywanych z rolnikami.

Większość danych rolniczych ma charakter danych nieosobowych - są to dane agronomiczne, dotyczące ziemi, działek rolnych, sposobów uprawy, stanu i zdrowia zwierząt, wykorzystania maszyn czy wyników produkcji. Choć do analiz big data wykorzystywane są zagregowane i zanimizowane dane z wielu gospodarstw rolnych, obecne metody eksploracji danych i krzyżowych zestawień baz danych pozwalają łączyć dane nieosobowe z danymi osobowymi ${ }^{39}$. W rezultacie dzięki łączeniu danych z różnych rejestrów i systemów można wygenerować nie tylko informacje dotyczące procesów produkcji w konkretnym gospodarstwie, lecz także dane osobowe i informacje prywatne.

Możliwe naruszenia prawa do prywatności rolników mogą przybierać różne formy - od wykorzystywania uzyskanych danych kontaktowych do celów handlowych po ujawnianie wrażliwych informacji na temat stanu posiadania, zaciągniętych kredytów czy wysokości czynszów dzierżawnych za grunty orne. Praktyka pokazuje, że głównym źródłem problemów w tym obszarze są nie tyle nieuprawnione działania podmiotów trzecich, ile przepływy danych między spółkami, które są ze sobą związane porozumieniami o partnerstwie i współpracy ${ }^{40}$. Naruszenia prawa do

37 Zob. L. Wiseman, J. Sanderson, L. Robb, Rethinking ag data ownership, „Farm Policy Journal” 2018, t. 15, nr 1, s. 76.

38 S. Wachter, B. Mittelstadt, A Right to Reasonable Inferences: Re-Thinking Data Protection Law in the Age of Big Data and AI, "Columbia Business Law Review” 2019, nr 2, s. 500.

39 J. Stefanowski, N. Japkowicz, Final Remarks on Big Data Analysis and Its Impact on Society and Science [w:] Big Data Analysis: New Algorithms for a New Society, red. N. Japkowicz, J. Stefanowski, Springer, Cham 2016, S. 321.

40 Świadczy o tym m.in. przypadek współpracy między Climate Corporation (obecnie własność koncernu Bayer), która prowadzi platformę rolniczą FieldView, a spółką Tillable, która pośredniczy w zawieraniu umów między właścicielami i dzierżawcami gruntów rolnych. Oba przedsiębiorstwa w październiku 2019 r. ogłosiły porozumienie o partnerstwie, które - zgodnie z prasowymi deklaracjami - przewidywało integrację zasobów danych obu podmiotów. W lutym 2020 r. zarówno właściciele, jak i dzierżawcy gruntów rolnych zaczęli otrzymywać spersonalizowane oferty, w których proponowane ceny za dzierżawę nowych gruntów były bardzo zbliżone do rzeczywiście pobieranych i płaconych czynszów dzierżawnych. Uzyskanie tak do- 
prywatności mogą mieć rozmaite konsekwencje - od osobistych i społecznych po ekonomiczne i finansowe. Niedostateczna ochrona danych rolniczych może skutkować m.in. ujawnieniem wewnętrznego know-how produkcji w gospodarstwie bądź innych tajemnic handlowych gospodarstw prowadzących działalność w danej branży (sektorze, kraju).

\section{Problem koncentracji danych rolniczych}

Kolejny problem w ramach systemów rolnictwa inteligentnego dotyczy koncentracji danych rolniczych oraz nadmiernych korzyści uzyskiwanych przez „pierwszych graczy". Ze względu na szybko osiągane korzyści skali i zakresu pojedyncze przedsiębiorstwa mogą zgromadzić takie ilości danych, które de facto ograniczą możliwości działania innym podmiotom. Dostęp do danych jest zazwyczaj kontrolowany przez duże przedsiębiorstwa, które sprzedają maszyny i urządzenia posiadające systemy do gromadzenia i przesyłu danych. Przyrost danych kontrolowanych przez największe korporacje następuje również w wyniku coraz częstszych fuzji i przejęć (głównie szybko rozwijających się startupów z branży agrotech) ${ }^{41}$. Wraz ze sprzętem i maszynami rolniczymi przedsiębiorstwa te z reguły oferują rolnikom całe pakiety zdalnych usług serwisowych i cyfrowych, które są dodatkowym źródłem gromadzenia danych. Usługi te są najczęściej oferowane na podstawie modeli subskrypcyjnych. Rolnicy wnoszą opłatę abonamentową za dostęp do platformy, na której mogą znaleźć wskazówki oraz wytyczne dotyczące maszyn, ziemi, upraw czy zwierząt wygenerowane automatycznie przez algorytmy maszynowego uczenia się w oparciu o dane z ich gospodarstw zagregowane z danymi z innych źródeł. Równocześnie dostawcy technologii rolniczych posiadający wzajemnie uzupełniające się zasoby (m.in. producenci kombajnów rolniczych, spryskiwaczy, środków agrochemicznych) tworzą grupy i partnerstwa w celu dostarczania rolnikom kompletnych usług spełniających ich potrzeby ${ }^{42}$. Współpracujące podmioty przyjmują wspólne standardy w celu zapewnienia interoperacyjności baz danych, co usprawnia proces korzystania ze zgromadzonych zasobów danych rolniczych ${ }^{43}$. Zarazem prywatnie uzgadniane standardy interoperacyjności w zakresie proce-

kładnych informacji o stawkach czynszów dzierżawnych było możliwe właściwie tylko poprzez platformę FieldView, na której takie dane są zamieszczane. W rezultacie niektórzy rolnicy zaczęli rezygnować z usług obu spółek. Choć po nagłośnieniu sprawy oba przedsiębiorstwa zaprzeczyły, by doszło do udostępnienia danych w tym obszarze, zdecydowały równocześnie o zakończeniu partnerstwa. Zob. T. Janzen, The FieldView-Tillable Breakup: What Went Wrong, The Janzen Ag Tech Blog, 18 February 2020, https://www.aglaw.us/ janzenaglaw/2020/2/18/the-fieldview-tillable-breakup [dostęp: 22 maja 2020 r.].

41 OECD, Enhancing Access..., s. 16.

42 Przykładowo, spółka John Deere, produkująca maszyny rolnicze, oferuje również platformę FarmSight - produkt rolnictwa inteligentnego (cyfrowego), który pozwala monitorować prace wykonywane w gospodarstwie, w tym wydajność wykorzystywanych środków agronomicznych. John Deere przy rozwoju swoich produktów i usług współpracował z BASF, Bayer-Monsanto, i DowDupont. Z kolei przy rozwoju usług na platformie FieldView spółka Climate Corporation (Bayer-Monsanto) współpracowała z CNH, John Deere, AGCO i Agrium. X. Pham, M. Stack, How data analytics is transforming agriculture, „Business Horizons” 2018, t. 61, nr 1, s. 132.

43 M. Hopkins, ADAPT Conversion Toolkit Making In Roads With Equipment Manufacturers, 22 September 2016, https://www.precisionag.com/digital-farming/data-management/adapt-conversion-toolkit-making-in-roads-with-equipment-manufacturers/ [dostęp: 4 czerwca 2020 r.]. 
sów biznesowych, kwestii technicznych i semantycznych mogą ograniczać dostęp do danych przedsiębiorstwom konkurencyjnym. W rezultacie rolnicy funkcjonujący w systemach rolnictwa inteligentnego często zdani są na produkty i usługi niewielkiej grupy podmiotów, które mogą stosunkowo swobodnie decydować o cenach. Zarówno kompleksowe oferty produktów i usług cyfrowych, jak i prywatne standardy interoperacyjności prowadzą do uzależnienia gospodarstw rolnych od systemów tworzonych przez pojedynczych dostawców (lock-in effect). Nawet jeśli rolnicy zdecydują się na przeniesienie surowych danych do innego dostawcy, dodatkowe czynności związane z ich przetwarzaniem mogą przełożyć się na znaczne podniesienie kosztów rozwoju nowych produktów i usług cyfrowych. Kompleksowe pakiety produktów i usług od jednego dostawcy bądź od współpracujących ze sobą dostawców są też zazwyczaj dla rolników wygodniejszym rozwiązaniem niż zakup wielu różnych produktów i usług cyfrowych. Czas potrzebny na naukę nowych aplikacji i programów oraz niepewność co do ich dopasowania do maszyn wykorzystywanych w gospodarstwie mogą zniechęcać rolników do zmiany. Czynniki te prowadzą de facto do ograniczonego przepływu danych rolniczych i w konsekwencji do niedostatecznej konkurencji na rynku produktów i usług cyfrowych dla rolnictwa inteligentnego.

\section{Nierówny poziom danetyzacji gospodarstw rolnych}

Proces cyfryzacji w sektorze rolnym przebiega w sposób nierównomierny i asymetryczny. Na tempo cyfrowych zmian i danetyzację gospodarstw rolnych, czyli możliwości gromadzenia i rejestrowania danych opisujących oraz obrazujących procesy i zjawiska związane z prowadzoną działalnością rolniczą, wpływa szereg czynników. Kluczowe dla danetyzacji w sektorze rolnym są dobrze rozwinięta infrastruktura cyfrowa na obszarach wiejskich, w tym dostęp do łączy komórkowych i szerokopasmowych, prężny ekosystem przedsiębiorstw zajmujących się rozwojem innowacyjnych produktów i usług cyfrowych dla rolnictwa, dostęp do kapitału i źródeł finansowania zakupu nowoczesnych maszyn i urządzeń rolniczych oraz systemy edukacji i doradztwa rolniczego uwzględniające nowe potrzeby w zakresie kształcenia umiejętności i kompetencji cyfrowych ${ }^{44}$.

Decyzje rolników o wejściu na drogę cyfrowych zmian wydają się także skorelowane z wielkością gospodarstw rolnych oraz wcześniej zdobytym doświadczeniem w zakresie wykorzystania technologii informacyjno-komunikacyjnych. Generalnie, cyfrowe zmiany wdrażają chętniej i szybciej właściciele oraz dzierżawcy dużych i bardzo dużych gospodarstw rolnych oraz ci rolnicy, którzy stosowali wcześniej techniki rolnictwa precyzyjnego ${ }^{45}$. Rolnicy w obu tych grupach mają na ogół wyższe dochody oraz wyższy poziom wykształcenia niż w pozostałych grupach rolników. W niektórych państwach trend do koncentracji technologii cyfrowych i danetyzacji w największych gospodarstwach rolnych jest bardzo widoczny. Dotyczy to przede

44 N.M. Trendov, S. Varas, M. Zeng, Digital technologies in agriculture and rural areas - Status report, FAO, Rome 2019, s. 3-4.

45 M. Kernecker et al., Experience versus expectation: farmers' perceptions of smart farming technologies for cropping systems across Europe, „Precision Agriculture” 2020, t. 21, nr 1, s. 39, https://doi.org/10.1007/s11119019-09651-z. 
wszystkim państw, w których rolnictwo precyzyjne wprowadzono najwcześniej (jak w północnej Europie, USA czy Australii) ${ }^{46}$. Jednak również w mniej zaawansowanych pod względem cyfrowym państwach można zauważyć, że z nowych technologii korzystają najczęściej największe gospodarstwa rolne ${ }^{47}$.

Małe i bardzo małe gospodarstwa rolne zazwyczaj nie decydują się na zakup zaawansowanych maszyn i urządzeń rolniczych wyposażonych w czujniki, które są obecnie głównym narzędziem zbierania granularnych danych o produkcji rolnej. Zakup tego rodzaju urządzeń jest najczęściej poza zasięgiem finansowym właścicieli tego typu gospodarstw. W wielu wypadkach jest też nieuzasadniony ze względu na skalę prowadzonej działalności. W rezultacie rynek produktów i usług cyfrowych dla mniejszych gospodarstw rolnych, gospodarstw prowadzących zróżnicowane uprawy i chów zwierząt, jak również gospodarstw ekologicznych jest słabiej rozwinięty niż rynek produktów i usług dla gospodarstw wielkoobszarowych oraz prowadzących przemysłowy chów zwierząt. Rozproszenie danych z gospodarstw mniejszych oznacza, że trudniej jest nie tylko wydobywać wartość z danych (np. w analizach predykcyjnych), lecz także osiągać korzyści skali i zakresu, które są kluczowe dla dostawców rozwiązań cyfrowych.

Uwarunkowania te sprawiają, że poziom danetyzacji w sektorze rolnym jest zróżnicowany wyższy w największych i najzamożniejszych gospodarstwach, niższy w tych mniejszych i biedniejszych. Z tego względu, że wykorzystanie danych w dużej mierze przekłada się na wzrost produktywności i efektywności, nierówne tempo danetyzacji może pogłębiać nierówności dochodowe w sektorze rolnym. Równocześnie ze względu na wskazane uwarunkowania strukturalne oraz wcześniej realizowane ścieżki rozwoju (rolnictwo przemysłowe versus rolnictwo tradycyjne) wydaje się, że bez odpowiedniego wsparcia zwiększenie ilości danych generowanych w sektorze rolnym może być w niektórych państwach bardzo trudne. Nierówności w tym obszarze mogą przekładać się zarówno na gorsze perspektywy rozwoju poszczególnych gospodarek żywnościowych, jak i na nierówne warunki konkurowania na rynkach międzynarodowych.

\section{Niewystarczająca współpraca sektora prywatnego i sektora publicznego w łańcuchu wartości dużych zbiorów danych w rolnictwie}

Do niedawna podmiotem dominującym w systemach gromadzenia danych dotyczących gospodarstw rolnych i produkcji rolnej było państwo. W statystykach publicznych można odnaleźć rozbudowane bazy danych dotyczące m.in. struktury obszarowej gospodarstw rolnych, struktury produkcji, plonów i wielkości produkcji, cen rolnych, produktywności ziemi i pracy, dochodów rolniczych i innych wielkości opisujących rozwój sektora rolnego i obszarów wiejskich. Jednocześnie sektor publiczny rozwija i utrzymuje infrastrukturę informacji przestrzennej, w tym

46 Przykładowo w Danii kombajny z systemami RTK-GPS wykorzystywało $16 \%$ gospodarstw rolnych, zajmowały one jednak aż 45\% użytków rolnych w tym kraju. S.M. Pedersen, PAMCoBA - Cost Benefit of Digitisation, ICT-AGRI Seminar, Copenhagen, 24.11.2017.

47 Przykładem może być rolnictwo w Rosji, gdzie w 2018 r. funkcjonowało zaledwie 1600 gospodarstw precyzyjnych. Zajmowały one jednak aż 10\% wszystkich użytków rolnych w tym kraju. B. Frumkin, Russia: on the way to "Agriculture 4.0", Report for the IAFE-NRI Conference, 11-13 June 2018, Lidzbark Warmiński. 
systemy teledetekcji satelitarnej. Dzięki temu możliwe jest gromadzenie danych georeferencyjnych, danych katastralnych, danych obiektów topograficznych, map i obrazów satelitarnych działek rolnych i upraw, danych środowiskowych i innych danych przestrzennych ${ }^{48}$. Co do zasady jednak sektor publiczny nie wykorzystuje gromadzonych danych do rozwoju produktów i usług, których celem byłyby poprawa efektywności procesów produkcji czy wdrażanie bardziej zrównoważonych praktyk rolniczych. Głównym celem jest monitorowanie efektów i skuteczności polityk publicznych dotyczących rolnictwa i obszarów wiejskich oraz kontrola spełniania przez gospodarstwa rolne wymogów ustawowych ${ }^{49}$.

Sektor prywatny korzysta z dostępu do otwartych danych publicznych i równocześnie gromadzi duże ilości danych rolniczych z maszyn i czujników sprzedawanych rolnikom. Dane sektora prywatnego dotyczące produkcji roślinnej i zwierzęcej mają bardzo szczegółowy charakter, są bowiem zbierane bezpośrednio w gospodarstwie rolnym. W połączeniu z dodatkowymi źródłami danych mają więc bardzo dużą wartość. W rezultacie sektor prywatny odgrywa coraz istotniejszą rolę w systemach gromadzenia danych rolniczych. Zarazem efekty zewnętrzne działalności rolniczej każą zastanowić się nad możliwością otwarcia dostępu do odpowiednio zanonimizowanych i zagregowanych prywatnych danych rolniczych. Dane te - w połączeniu z innymi źródłami danych - mogłyby składać się na nowe zasoby wiedzy, kluczowe z punktu widzenia wspierania zrównoważonego rozwoju sektora rolnego, zapewniania bezpieczeństwa żywnościowego oraz ochrony klimatu czy środowiska naturalnego ${ }^{50}$. Mogłyby również istotnie zwiększyć możliwości prowadzenia polityk publicznych opartych na dowodach (evidence-based policies). Obecnie jednak współpraca instytucji sektora publicznego i przedsiębiorstw prywatnych w łańcuchu wartości dużych zbiorów danych rolniczych jest ograniczona, co prowadzi do dużych strat społecznych. Najistotniejsze będą zatem działania i regulacje, które będą poprawiać perspektywy współpracy sektora publicznego i prywatnego w zakresie wymiany i wykorzystywania danych rolniczych do realizacji celów i działań istotnych z punktu widzenia szerszych interesów społecznych.

\section{Ramy rozwoju rolnictwa inteligentnego - aspekty regulacyjne}

Szybkie tempo zmian w gospodarce związane z coraz szerszym wykorzystaniem technologii cyfrowych i nowych modeli biznesowych sprawia, że wypracowanie przepisów prawa i regulacji dopasowanych do aktualnych potrzeb i wyzwań jest niezwykle trudne ${ }^{51}$. Stosunkowo często pierwszym wyborem regulatorów są instrumenty miękkiego prawa (m.in. wytyczne i rekomen-

48 Dane satelitarne dla administracji publicznej, https://polsa.gov.pl/images/Sat4Envi/Broszura_calosc_pdf [dostęp: 7 czerwca 2020 r.].

49 K. Kosior, Towards a New Data Economy for EU Agriculture, "Studia Europejskie - Studies in European Affairs" 2019, nr 4, s. 96, https://doi.org/10.33067/SE.4.2019.6.

50 Ibidem, s. 100.

51 Z tego względu rozwijane są nowe podejścia i narzędzia, które mają pomagać przy wyborze właściwych rozwiązań legislacyjnych. Zob. więcej: K. Marchewka-Bartkowiak, Nowe rozwiqzania regulacyjne - RIA, sandbox, compliance, RegTech - wświetle procesu "inflacji” prawa finansowego " "Studia BAS" 2018, nr 1, s. 135-148. 
dacje), które pozwalają ocenić gotowość interesariuszy do przyjęcia i stosowania określonych norm prawnych. W sektorze rolnym nie uchwalono jak dotąd odrębnych regulacji, w których określono by zasady zarządzania dużymi zbiorami danych rolniczych. W ostatnim okresie w niektórych krajach i regionach pojawiły się jednak nieformalne wytyczne i kodeksy dobrych praktyk w zakresie przepływu i udostępniania danych pochodzących z systemów rolnictwa inteligentnego. W UE wydano również w ostatnich latach nowe rozporządzenia dotyczące swobodnego przepływu danych osobowych i nieosobowych, mające charakter horyzontalny. Dodatkowo w 2020 r. Unia Europejska przyjęła nową strategię, której celem jest stworzenie europejskich przestrzeni danych w różnych obszarach i sektorach. Zarówno nieformalne wytyczne dotyczące zarządzania danymi rolniczymi, jak i nowe działania legislacyjne w UE związane z tworzeniem europejskiej przestrzeni danych mogą mieć istotny wpływ na łańcuch wartości dużych zbiorów danych rolniczych.

\section{Sektorowe standardy i wytyczne dotyczące zarządzania danymi rolnictwa inteligentnego}

Wypracowywane na poziomie sektora standardy i wytyczne dotyczące zarządzania danymi rolniczymi stanowią punkt odniesienia dla umów, które rolnicy podpisują z dostawcami technologii rolniczych i cyfrowych. Celem sektorowych wytycznych i standardów jest wskazanie zestawu reguł, które zapewniałyby bezpieczny, transparentny i efektywny przepływ danych w łańcuchu wartości danych. Standardy wypracowywane są głównie w tych krajach, w których świadomość ekonomicznego znaczenia danych rolniczych jest największa. Kodeksy i standardy takie funkcjonują już m.in. w USA, Nowej Zelandii i Unii Europejskiej ${ }^{52}$.

W USA działania na rzecz wypracowania standardów zarządzania danymi rolniczymi zapoczątkowała w 2014 r. organizacja American Farm Bureau Federation, reprezentująca zarówno gospodarstwa rolne, jak i wielkie korporacje przemysłu rolnego. Z jej inicjatywy przyjęto w 2016 r. porozumienie na rzecz przejrzystego zarządzania danymi rolniczymi (Ag Data Transparent Initiative $)^{53}$. W porozumieniu znalazło się odniesienie do kwestii praw własności rolników do danych, konieczności uzyskania zgody od rolników na gromadzenie danych i ich przetwarzanie, obowiązku informowania rolników o podmiotach trzecich posiadających dostęp do danych oraz o celach przetwarzania danych. Inne istotne wytyczne dotyczą zapewnienia możliwości wyboru tylko niektórych usług z oferowanych pakietów i równocześnie informowania rolników o konsekwencjach przyjęcia bądź odrzucenia określonych opcji i usług opartych na danych. Zgodnie z porozumieniem rolnicy mają również prawo do otrzymania i przenoszenia niezanonimizowanych i niezagregowanych danych dotyczących ich gospodarstw oraz do wystosowania wniosku o usunięcie ich danych z baz danych podmiotów, które je gromadzą. Zarazem w wytycznych wskazuje się na konieczność uwzględniania w umowach zapisów dotyczących odpowiedzialności dostawców cyfrowych technologii rolniczych za możliwe naruszenia prawa

\footnotetext{
52 L. Wiseman et al., Review of codes of conduct, voluntary guidelines and principles relevant for farm data sharing, "CTA Working Paper" 2019, nr 1, s. 3-14.

53 Ag Data Transparent Initiative, https://www.agdatatransparent.com/about [dostęp: 7 czerwca 2020 r.].
} 
do prywatności rolników i niedostateczne zabezpieczenia baz danych przed nieuprawnionym dostępem, zniszczeniem bądź utratą danych. Przedsiębiorstwa, które w proponowanych rolnikom umowach uwzględniają wypracowane wytyczne i dobre praktyki zarządzania danymi, mogą uzyskać certyfikat Ag Data Transparent.

W kodeksie nowozelandzkim (Farm Data Code of Practice), ogłoszonym w 2014 r., nacisk położony jest zarówno na kwestie bezpieczeństwa danych rolniczych, jak i na kwestie związane z ułatwianiem dostępu do danych w celu wspierania innowacji ${ }^{54}$. Kodeks wymaga, by organizacje i przedsiębiorstwa gromadzące dane rolnicze udostępniały opisy działań podejmowanych w celu ochrony danych rolników. Przedsiębiorstwa są także zobowiązane do stosowania wspólnych standardów dla danych, co ma umożliwiać łatwiejszy i szybszy przepływ danych w łańcuchu wartości. Przedsiębiorstwa gromadzące dane i podmioty trzecie uzyskujące dostęp do danych muszą zapewnić bezpieczeństwo danym oraz chronić prywatność rolników. Kwestie praw własności do danych rolniczych nie zostały w kodeksie nowozelandzkim doprecyzowane. Jednocześnie jednak podkreślana jest waga respektowania praw własności intelektualnej oraz wspierania innowacji, co de facto wzmacnia pozycję podmiotów przetwarzających dane w łańcuchu wartości danych. Zarazem wymóg stawiany przedsiębiorstwom odnośnie do konieczności uzyskiwania zgód rolników na gromadzenie, przechowywanie oraz udostępnianie danych podmiotom trzecim wskazuje na uznanie praw własności rolników do danych surowych. Rolnik ma prawo przeglądać, korygować oraz wydobywać dane dotyczące jego gospodarstwa rolnego z systemów informatycznych przedsiębiorstw gromadzących dane. Ma mieć również zapewnioną możliwość przekazywania danych innym przedsiębiorstwom i podmiotom, które mogą świadczyć usługi na rzecz gospodarstwa.

W UE kodeks postępowania w zakresie udostępniania cyfrowych danych rolniczych został przyjęty w 2018 r. przez dziesięć europejskich stowarzyszeń i organizacji reprezentujących rolników i producentów środków produkcji dla rolnictwa (COPA i COGECA, CEMA, CEETTAR, ESA, Fertilizers Europe, FEFAC, ECPA, EFFAB, CEJA) ${ }^{55}$. W kodeksie europejskim można znaleźć odrębne zapisy poświęcone prawom własności do danych, kwestiom dostępu do danych, kontroli danych i przenoszenia danych, problemowi przejrzystości umów, bezpieczeństwa danych i ochrony prywatności, jak i zagadnieniom związanym z ochroną praw własności intelektualnej uczestników łańcucha wartości danych. Kodeks wskazuje, że prawa własności do danych należą do podmiotu, który dane wygenerował. Dane zatem wytworzone w gospodarstwie na skutek aktywności rolnika są jego własnością. Rolnik jako właściciel danych decyduje o tym, kto ma prawo dostępu do danych z jego gospodarstwa i korzystania z nich. Prawo to nie rozciąga się jednak na dane, które zostały przetworzone i zagregowane z danymi innych gospodarstw rolnych. Równocześnie rolnicy mają mieć zagwarantowane prawo dostępu do swoich danych oraz techniczną możliwość przenoszenia danych między platformami i usługodawcami. Podobnie jak kodeksy amerykański i nowozelandzki, kodeks europejski

54 Farm Data Code of Practice. Version 1.1, http://www.farmdatacode.org.nz/wp-content/uploads/2016/03/ Farm-Data-Code-of-Practice-Version-1.1_lowres_singles.pdf [dostęp: 7 czerwca 2020 r.].

55 EU Code of conduct on agricultural data sharing by contractual agreement, https://www.copa-cogeca.eu/img/ user/files/EU\%20CODE/EU_Code_2018_web_version.pdf [dostęp: 8 czerwca 2020 r.]. 
odnosi się do kwestii ochrony prywatności i bezpieczeństwa danych. Strony mogą uzgodnić w umowie, w jakich przypadkach dopuszczalna jest identyfikacja właściciela danych. W pozostałych sytuacjach dane powinny zostać poddane pseudonimizacji. W kodeksie europejskim pojawia się dodatkowo bezpośrednie odniesienie do kwestii udziału w korzyściach wynikających z gromadzenia i wykorzystywania danych rolniczych. Kodeks stwierdza, że rolnicy bądź inne podmioty generujące dane w gospodarstwie mają prawo otrzymać wynagrodzenie za wytworzoną wartość w formie pieniężnej bądź niepieniężnej (np. w postaci ulepszonych produktów lub usług).

Jak pokazuje powyższy przegląd, wypracowane w USA, Nowej Zelandii i UE standardy i kodeksy dotyczące zarządzania danymi z systemów rolnictwa cyfrowego są do siebie zbliżone. Również przyjęty na początku 2020 r. kodeks australijski (Farm Data Code) nawiązuje do wskazanych wyżej standardów i zasad zarządzania danymi rolniczymi ${ }^{56}$. Kodeks australijski, podobnie jak kodeks europejski, wskazuje na wagę zapewnienia rolnikom prawa do korzyści związanych z gromadzeniem i wykorzystywaniem ich indywidualnych danych rolniczych. Choć przyjmowane na poziomie sektora kodeksy są dowodem na dążenie jego przedstawicieli do stworzenia czytelnych zasad zarządzania danymi rolniczymi, są także uznawane za niewystarczający instrument porządkowania relacji i procesów w systemach rolnictwa cyfrowego ${ }^{57}$. Duży wpływ na zakres i charakter standardów ujmowanych w kodeksach miały związki i organizacje zrzeszające dużych producentów maszyn i technologii rolniczych. Podmioty mniejsze, w tym startupy agtech i inne przedsiębiorstwa działające na rynku danych, nie odegrały większej roli w procesie określania zasad zarządzania danymi z systemów rolnictwa cyfrowego. Słabym punktem wypracowywanych na poziomie sektora standardów dla rolnictwa cyfrowego jest też ich ograniczony charakter. Przyjęte kodeksy koncentrują się wyłącznie na prywatnym łańcuchu wartości dużych zbiorów danych. Tym samym pomijają ważny publiczny wymiar cyfrowych danych rolniczych, w tym istotne funkcje sektora rolnego w zakresie dostarczania środowiskowych i innych dóbr publicznych.

\section{Kierunki działań i inicjatyw regulacyjnych UE}

Rozwój nowoczesnych i zrównoważonych systemów produkcyjnych w rolnictwie, wykorzystujących technologie cyfrowe i dane, jest jednym z priorytetów Unii Europejskiej. Choć nie ma odrębnego programu na rzecz cyfryzacji rolnictwa, instytucje UE i państwa członkowskie podejmują wiele inicjatyw i działań, które mają uławiać wykorzystanie danych i technologii cyfrowych w sektorze rolnym. Bezpośrednie znaczenie dla łańcucha wartości dużych zbiorów danych w rolnictwie mają działania podejmowane w obszarze jednolitego rynku cyfrowego. Realizowany od 2015 r. program budowy jednolitego rynku cyfrowego stopniowo dostosowuje

56 Farm Data Code. Edition 1. February 2020, https://nff.org.au/wp-content/uploads/2020/02/Farm_Data_Code_ Edition_1_WEB_FINAL.pdf [dostęp: 8 czerwca 2020 r.].

57 J. Sanderson, L. Wiseman, S. Poncini, What's behind the ag-data logo? An examination of voluntary agricultural-data codes of practice, "International Journal of Rural Law and Policy” 2018, nr 1, s. 16, https://doi. org/10.5130/ijlp.1.2018.6043. 
ustawodawstwo europejskie do nowych wymogów i potrzeb związanych z likwidowaniem barier na drodze do swobodnego przepływu danych cyfrowych między państwami członkowskimi. Od 2018 r. w UE obowiązuje ogólne rozporządzenie o ochronie danych, uwzględniające zarówno potrzebę zapewnienia pełnej swobody przepływu danych osobowych na obszarze jednolitego rynku cyfrowego, jak i potrzebę wzmocnienia prawa obywateli UE do ochrony prywatności ${ }^{58}$. W 2018 r. przyjęto również nowe rozporządzenie w sprawie ram swobodnego przepływu danych nieosobowych w UE ${ }^{59}$. Wprowadzone rozporządzenie odnosi się do danych innych niż dane osobowe, w tym do danych generowanych w sposób automatyczny przez maszyny, czujniki i urządzenia komunikujące się ze sobą w internecie rzeczy.

W obu rozporządzeniach zawarto przepisy, które mają kluczowe znaczenie zarówno dla rozwoju łańcucha wartości dużych zbiorów danych w rolnictwie, jak i dla perspektyw rozwiązania niektórych ze wskazywanych wcześniej problemów rolnictwa cyfrowego. Unijni i zagraniczni dostawcy produktów i usług cyfrowych dla rolnictwa zobowiązani są obecnie do stosowania rozwiązań wzmacniających ochronę prywatności swoich klientów, m.in. do uwzględniania zasady minimalizacji danych, zasady ochrony prywatności już na etapie projektowania produktów i usług (privacy by design) oraz zasady domyślnej prywatności (privacy by default), oznaczającej konieczność uzyskiwania dodatkowych zgód na przetwarzanie danych osobowych, które wykraczają poza zakres niezbędny do świadczenia usług ${ }^{60}$. Przepisy rozporządzenia o ochronie danych osobowych mogą mieć zastosowanie także do danych nieosobowych, jeśli dane te zostaną przekształcone i połączone z danymi osobowymi rolników. W rozporządzeniu o swobodnym przepływie danych nieosobowych wprowadzony został zakaz stosowania przez państwa członkowskie wymogów dotyczących lokalizacji danych. Wymogi te wcześniej istotnie ograniczały mobilność danych nieosobowych w UE i tym samym możliwości rozwoju konkurencyjnej oferty produktów i usług opartych na danych. W rozporządzeniu zawarto dodatkowo wymóg adresowany do sektora prywatnego dotyczący tworzenia kodeksów postępowania w zakresie przenoszenia danych między dostawcami usług ${ }^{61}$. Efektem rozporządzenia może być więc większa konkurencja na rynku produktów i usług cyfrowych dla rolnictwa.

Osiągnięciu tego celu mogą sprzyjać również wytyczne dla podmiotów sektora prywatnego w zakresie udostępniania i przepływu danych, które Komisja Europejska opublikowała wiosną 2018 r. w ramach serii komunikatów dotyczących gospodarki opartej na danych. Podkreślono w nich wagę zasady przejrzystości umów, uznania roli różnych podmiotów w tworzeniu wartości danych, poszanowania interesów handlowych stron umów oraz zapewnienia niezakłóconej kon-

58 Rozporządzenie Parlamentu Europejskiego i Rady (UE) 2016/679 z dnia 27 kwietnia 2016 r. w sprawie ochrony osób fizycznych w związku z przetwarzaniem danych osobowych i w sprawie swobodnego przepływu takich danych oraz uchylenia dyrektywy 95/46/WE (ogólne rozporządzenie o ochronie danych), Dz.Urz. UE L 2016.119.1.

59 Rozporządzenie Parlamentu Europejskiego i Rady (UE) 2018/1807 z dnia 14 listopada 2018 r. w sprawie ram swobodnego przepływu danych nieosobowych w Unii Europejskiej, Dz.Urz. UE L 2018.303.59.

60 The Governance of Data in a Digitally Transformed European Society, red. M. Micheli, M. Blakemore, M. Ponti, M. Craglia, JRC Conference and Workshop Reports, Publications Office of the European Union, Luxembourg 2018, s. 11.

61 K. Kosior, Towards a New Data Economy..., s. 103. 
kurencji i możliwości przenoszenia danych między dostawcami usług cyfrowych ${ }^{62}$. W tym samym dokumencie Komisja podkreśliła znaczenie przepływów danych cyfrowych z sektora prywatnego do sektora publicznego (B2G), zwłaszcza w tych obszarach, w których dane prywatne mogą pomóc w realizacji ważnych interesów publicznych. Choć nie przyjęto wytycznych w tym obszarze, wskazano możliwe modele współpracy między sektorem biznesu i rządem, takie jak nieodpłatne przekazywanie danych przez przedsiębiorstwa, ustanawianie nagród ze środków publicznych za rozwiązanie określonych problemów z wykorzystaniem danych prywatnych, formalne porozumienia i partnerstwa B2G czy dobrowolne przekazywanie danych przez obywateli63.

Instytucje UE kontynuują pracę nad regulacjami, które pozwoliłyby poprawić perspektywy rozwoju gospodarki opartej na danych. Przyjęte w ostatnich latach rozporządzania i wytyczne tworzą solidne ramy funkcjonowania jednolitego rynku cyfrowego - pozwalają na zwiększenie przepływów danych i równocześnie zwiększają ochronę prywatności danych osobowych. Wciąż jednak istnieje wiele barier utrudniających proces cyfrowej transformacji w Europie. Problemami są m.in. słaba pozycja osób fizycznych w łańcuchu wartości danych (w tym rolników), brak efektywnych mechanizmów pozwalających na ponowne wykorzystanie danych przenoszonych między dostawcami, brak ram pozwalających na szacowanie ekonomicznej wartości danych, brak ram służących pomiarowi przepływów danych, a także niedostateczny rozwój europejskiej infrastruktury chmurowej. Wychodząc naprzeciw tym deficytom i problemom, Komisja Europejska ogłosiła w lutym 2020 r. nową strategię w zakresie danych ${ }^{64}$. Jej celem jest zapewnienie warunków pozwalających na pełne wykorzystanie potencjału przyrastających zasobów danych w UE. Strategia kładzie zarazem nacisk na konieczność zapewnienia społeczeństwu jak najszerszych korzyści wynikających z cyfrowych zmian (tzw. cyfrowej dywidendy dla każdego). Proponowane jest przy tym badanie możliwości wykorzystania nowych rozwiązań (takich jak technologie rozproszonych baz danych, łańcuch bloków), które mogłyby realnie wzmacniać pozycję podmiotów słabszych, w tym osób fizycznych, w łańcuchu wartości danych ${ }^{65}$. Z wykorzystaniem zwinnych (agile) i eksperymentalnych podejść do tworzenia prawa (takich jak piaskownice regulacyjne) planowane jest wypracowanie międzysektorowych (horyzontalnych) regulacji zapewniających optymalne warunki dla rozwoju gospodarki opartej na danych, zgodnie z przyjętymi wartościami i zasadami. Nowe regulacje mają też uwzględniać specyfikę i potrzeby poszczególnych sektorów i obszarów działalności. Efektem realizacji strategii ma być europejska, w pełni interoperacyjna przestrzeń danych, złożona z wielu dziedzinowych przestrzeni danych (dotyczących przemysłu, Zielonego Ładu, transportu i mobilności, zdrowia, danych finansowych, energii, rolnictwa, administracji publicznej, umiejętności poszukiwanych na rynku pracy, danych

62 European Commission, Guidance on sharing private sector data in the European data economy. Accompanying the document: Communication from the Commission to the European Parliament, the Council, the European economic and social Committee and the Committee of the Regions "Towards a common European data space", Brussels, 25 April 2018, SWD(2018) 125 final.

63 Ibidem, s. 12-14.

64 Komunikat Komisji do Parlamentu Europejskiego, Rady, Europejskiego Komitetu Ekonomiczno-Społecznego i Komitetu Regionów, Europejska strategia w zakresie danych, COM(2020) 66 final, Bruksela, 19 lutego 2020 r.

65 Ibidem, s. 11. 
naukowych). Planowana wspólna przestrzeń danych dla rolnictwa zakłada możliwość stworzenia neutralnej platformy wymiany i agregowania danych dotyczących rolnictwa, obejmującej zarówno dane prywatne, jak i dane publiczne. Podejście i szczegółowe rozwiązania w tym obszarze mają uwzględniać ocenę funkcjonowania kodeksu postępowania w zakresie wymiany danych dotyczących rolnictwa, aktualną sytuację na rynku produktów i usług cyfrowych dla rolnictwa oraz możliwości wykorzystania funkcjonujących już przestrzeni danych dotyczących rolnictwa.

\section{Podsumowanie}

Rolnictwo znajduje się w okresie przełomowych zmian - nowe technologie cyfrowe i dane wpływają na usprawnienie procesów zarządzania gospodarstwami rolnymi oraz dają szansę na zwiększenie produkcji przy równoczesnym ograniczeniu zużycia środków produkcji. Cyfryzacja może więc pomóc w rozwiązaniu wielu wyzwań globalnych, przed jakimi stoi dziś światowe rolnictwo - wyżywienia rosnącej liczby ludności świata oraz ograniczenia negatywnego wpływu rolnictwa na środowisko przyrodnicze i zmiany klimatu. Doświadczenia poprzedniej rewolucji technologicznej w rolnictwie pokazują jednak, że rozwiązania usprawniające procesy w jednym obszarze mogą prowadzić do negatywnych zjawisk i procesów w innych obszarach. Również obecna rewolucja technologiczna w sektorze nie jest wolna od tych zagrożeń. Ze względu na podstawowe znaczenie rolnictwa i żywności odpowiednie wykorzystanie nowych technologii i danych cyfrowych powinno stanowić przedmiot zainteresowania i troski rządów, przedsiębiorstw i obywateli. Wspólnym celem powinien być łańcuch wartości dużych zbiorów danych dla rolnictwa, który pozwoli na realizację obietnic nowej rewolucji technologicznej i zarazem ograniczy możliwe negatywne konsekwencje cyfrowych zmian w rolnictwie.

W rozwijającym się ekosystemie rolnictwa cyfrowego kluczową rolę odgrywają duże i bardzo duże korporacje zajmujące się produkcją i sprzedażą maszyn i innych środków produkcji dla rolnictwa. Strategie biznesowe przedsiębiorstw tego sektora w coraz większym stopniu uwzględniają możliwości związane z monetyzacją danych rolniczych. Sprzęt rolniczy i środki produkcji dla rolnictwa sprzedawane są w pakietach wraz z oprogramowaniem i aplikacjami, które wspierają rolników w procesie podejmowania decyzji produkcyjnych. Z zaawansowanych maszyn i urządzeń wzbogaconych o rozwiązania cyfrowe korzystają głównie największe i najzamożniejsze gospodarstwa rolne. Choć ten kierunek cyfrowej transformacji może prowadzić do stosunkowo szybkiego wzrostu produktywności w sektorze, niekoniecznie będzie się przekładać na bardziej zrównoważone systemy produkcji rolniczej. Duża swoboda i uznaniowość dostawców usług cyfrowych w zakresie wyboru celów analiz danych rolniczych oznacza, że systemy rolnictwa inteligentnego mogą skupiać się na tych typach i rodzajach produkcji, które generują najwyższy zwrot z inwestycji w technologie cyfrowe. Obecnie nie ma ekonomicznych zachęt do gromadzenia danych z małych i średnich gospodarstw prowadzących bardziej zróżnicowaną czy ekologiczną produkcję rolną. W rezultacie w tej grupie gospodarstw problemem jest niewystarczająca podaż danych do prowadzenia bardziej zaawansowanych analiz. Utrzymujące się dysproporcje w poziomie danetyzacji gospodarstw rolnych mogą prowadzić do wzmocnienia procesów koncentracji produkcji i w konsekwencji do wzrostu nierówności dochodowych w sek- 
torze. Również efekty środowiskowe stosowania precyzyjnych technik produkcji w gospodarstwach wielkoobszarowych i wysokotowarowych w dłuższym okresie mogą być odwrotne od zamierzonych. Wypracowanie odpowiednich rozwiązań regulacyjnych wymaga pogłębionych badań społecznych oraz środowiskowych skutków rozwoju rolnictwa opartego na danych.

Obecne regulacje sektorowe i rozwiązania prawne tylko częściowo odpowiadają na nowe wyzwania związane z zarządzaniem danymi rolniczymi. Wciąż brakuje polityk i regulacji, które wspierałyby zrównoważony i inkluzywny rozwój rolnictwa w warunkach postępujących procesów cyfryzacji. Podmioty sektora prywatnego są zachęcane do wypracowywania standardów i kodeksów odnoszących się do zarządzania danymi z gospodarstw rolnych i udostępniania tych danych. Kodeksy te mają jednak ograniczony charakter i nie są prawnie wiążące. Nie rozwiązują też problemu słabej pozycji rolników w łańcuchu wartości danych, w tym problemu ograniczonych możliwości kontrolowania przepływów danych oraz przeszkód na drodze do ponownego wykorzystania danych z gospodarstw zmieniających dostawców. W obowiązujących regulacjach pominięto również ważne publiczne funkcje zagregowanych danych rolniczych (publicznych i prywatnych). Dane takie mogą mieć znaczenie dla wydobywania wiedzy istotnej nie tylko dla rolnictwa, lecz także dla innych powiązanych z rolnictwem obszarów i sektorów - środowiska naturalnego, klimatu czy zdrowia.

Planowane przez UE stworzenie europejskiej przestrzeni danych, w tym wspólnej przestrzeni danych rolniczych, uwzględniającej dane prywatne i dane publiczne, może wspierać rozwój zrównoważonego i inkluzywnego rolnictwa cyfrowego. Łańcuch wartości dużych zbiorów danych rolniczych, integrujący w możliwie najpełniejszym zakresie dostępne źródła danych, zwiększyłby szanse sektora rolnego na dostarczanie dóbr istotnych z punktu widzenia szerszych interesów społecznych. Dla osiągnięcia tych celów kluczowe będą zarówno uregulowania precyzujące zasady zarządzania danymi rolniczymi, jak i działania na poziomie polityk publicznych, m.in. rozwój infrastruktury cyfrowej na obszarach wiejskich, wsparcie zwiększenia kompetencji cyfrowych rolników oraz tworzenie zachęt dla rozwoju ekosystemu cyfrowego małych i ekologicznych gospodarstw rolnych. Ze względu na szeroki zakres realizowanych i planowanych działań w UE wydaje się, że regulacje i polityki unijne mogą stać się istotnym punktem odniesienia w procesie tworzenia ram dla rozwoju rolnictwa opartego na danych nie tylko w Europie, lecz także w innych częściach świata.

\section{Bibliografia}

Calvino F., Criscuolo Ch., Marcolin L., Squicciarini M., A taxonomy of digital intensive sectors, „OECD Science, Technology and Industry Working Papers" 2018, nr 14, OECD Publishing, Paris 2018.

Carbonell I.M., The ethics of big data in big agriculture, "Internet Policy Review” 2016, t. 5, nr 1, http://doi. org/10.14763/2016.1.405.

Curry E., The Big Data Value Chain: Definitions, Concepts, and Theoretical Approaches [w:] New Horizons for a Data-Driven Economy. A Roadmap for Usage and Exploitation of Big Data in Europe, red. J.M. Cavanillas, E. Curry, W. Wahlster, Springer, Cham 2016.

Darnell R. et al., The Current and Future State of Australian Agricultural Data, "Farm Policy Journal” 2018, t. 15, nr 1. 
Duch-Brown N., Martens B., Mueller-Langer F., The economics of ownership, access and trade in digital data, „JRC Working Papers on Digital Economy" 2017-01.

Faroukhi A.Z., El Alaoui I., Gahi Y., Amine A., Big data monetization throughout Big Data Value Chain: a comprehensive review, „Journal of Big Data” 2020, 7:3, https://doi.org/10.1186/s40537-019-0281-5.

Frumkin B., Russia: on the way to "Agriculture 4.0", Report for the IAFE -NRI Conference, 11-13 June 2018, Lidzbark Warmiński.

The Governance of Data in a Digitally Transformed European Society, red. M. Micheli, M. Blakemore, M. Ponti, M. Craglia, JRC Conference and Workshop Reports, Publications Office of the European Union, Luxembourg 2018.

Isitor E., Stanier C., Defining Big Data [w:] Proceedings of the International Conference on Big Data and Advanced Wireless Technologies. BDAW 2016, New York 2016.

Jakku E. et al., "If they don't tell us what they do with it, why would we trust them?" Trust, transparency and benefit-sharing in Smart Farming , „NJAS -Wageningen Journal of Life Sciences” 2019, t. 90-91, https://doi.org/10.1016/j. njas.2018.11.002.

Kerber W., Data-sharing in IoT ecosystems from a competition law perspective: The example of connected cars, „MAGKS Joint Discussion Paper Series in Economics" 2019, nr 21.

Kernecker M. et al., Experience versus expectation: farmers' perceptions of smart farming technologies for cropping systems across Europe „ „Precision Agriculture” 2020, t. 21, nr 1, https://doi.org/10.1007/s11119-019-09651-z.

Kosior K., Big data w sektorze publicznym - szanse, ograniczenia, perspektywy, „Kultura i Polityka” 2016, nr 20.

Kosior K., Towards a New Data Economy for EU Agriculture, "Studia Europejskie - Studies in European Affairs" 2019, nr 4, https://doi.org/10.33067/SE.4.2019.6.

Marchewka-Bartkowiak K., Nowe rozwiqzzania regulacyjne - RIA, sandbox, compliance, RegTech - w świetle procesu "inflacji” prawa finansowego, „Studia BAS" 2018, nr 1.

Moro Visconti R., Larocca A., Marconi M., Big Data-Driven Value Chains and Digital Platforms: From Value Co-Creation to Monetization, 2017, http://dx.doi.org/10.2139/ssrn.2903799.

Munné R., Big Data in the Public Sector [w:] New Horizons for a Data-Driven Economy. A Roadmap for Usage and Exploitation of Big Data in Europe, red. J.M. Cavanillas, E. Curry, W. Wahlster, Springer, Cham 2016.

OECD, Data in the digital age „OECD Going Digital Policy Note”, Paris 2019, www.oecd.org/going-digital/data-in-the-digital-age.pdf.

OECD, Enhancing Access to and Sharing of Data: Reconciling Risks and Benefits for Data Re-use across Societies, OECD Publishing, Paris 2019, https://doi.org/10.1787/276aaca8-en.

OECD, Vectors of Digital Transformation, „OECD Digital Economy Papers” 2019, nr 273, OECD Publishing, Paris, https://doi.org/10.1787/5ade2bba-en.

Pedersen S.M., PAMCoBA - Cost Benefit of Digitisation, ICT-AGRI Seminar, Copenhagen, 24.11.2017.

Pham X., Stack M., How data analytics is transforming agriculture, „Business Horizons” 2018, t. 61, nr 1.

Prainsack B., Logged out: Ownership, exclusion and public value in the digital data and information commons, „Big Data \& Society" 2019, t. 6, nr 1, https://doi.org/10.1177/2053951719829773.

Sadowski J., When data is capital: Datafication, accumulation, and extraction, „Big Data \& Society” 2019, t. 6, nr 1, https://doi.org/10.1177/2053951718820549.

Sanderson J., Wiseman L., Poncini S., What's behind the ag-data logo? An examination of voluntary agricultural-data codes of practice, „International Journal of Rural Law and Policy” 2018, nr 1, https://doi.org/10.5130/ ijrlp.1.2018.6043. 
van Schalkwyk F., Andrason A., Magalhaes G., A New Harvest: A Review of the Literature on Data Ownership Focusing on the Agricultural Sector, 29 October 2018, http://dx.doi.org/10.2139/ssrn.3379530.

Sonka S., Big Data: Fueling the Next Evolution of Agricultural Innovation, „JJournal of Innovation Management" 2016, t. 4, nr 1, https://doi.org/10.24840/2183-0606_004.001_0008.

Stefanowski J., Japkowicz N., Final Remarks on Big Data Analysis and Its Impact on Society and Science [w:] Big Data Analysis: New Algorithms for a New Society, red. N. Japkowicz, J. Stefanowski, Springer, Cham 2016.

Sykuta M.E., Big Data in Agriculture: Property Rights, Privacy and Competition in Ag Data Services, „International Food and Agribusiness Management Review" 2016, t. 19A (1030-2016-83141).

Tabakow M., Korczak J., Franczyk B., Big Data - definicje, wyzwania i technologie informatyczne, „Informatyka Ekonomiczna" 2014, nr 1(31).

Trendov N.M., Varas S., Zeng M., Digital technologies in agriculture and rural areas - Status report, FAO, Rome 2019. Wachter S., Mittelstadt B., A Right to Reasonable Inferences: Re-Thinking Data Protection Law in the Age of Big Data and AI, „Columbia Business Law Review” 2019, nr 2.

Wiseman L. et al., Review of codes of conduct, voluntary guidelines and principles relevant for farm data sharing, "CTA Working Paper" 2019, nr 1.

Wiseman L., Sanderson J., Robb L., Rethinking ag data ownership , „Farm Policy Journal” 2018, t. 15, nr 1.

Wiseman L., Sanderson J., Zhang A., Jakku E., Farmers and their data: An examination of farmers' reluctance to share their data through the lens of the laws impacting smart farming , "NJAS - Wageningen Journal of Life Sciences" 2019, t. 90-91, https://doi.org/10.1016/j.njas.2019.04.007.

Wolfert S., Ge L., Verdouw C., Bogaardt M.J., Big Data in Smart Farming - A review, „Agricultural Systems” 2017, t. 153, https://doi.org/10.1016/j.agsy.2017.01.023.

\section{Źródła internetowe, dokumenty i akty prawne}

Ag Data Transparent Initiative, https://www.agdatatransparent.com/about.

Dane satelitarne dla administracji publicznej, https://polsa.gov.pl/images/Sat4Envi/Broszura_calosc_.pdf.

EU Code of conduct on agricultural data sharing by contractual agreement, https://www.copa-cogeca.eu/img/user/ files/EU\%20CODE/EU_Code_2018_web_version.pdf.

European Commission, Guidance on sharing private sector data in the European data economy. Accompanying the document: Communication from the Commission to the European Parliament, the Council, the European economic and social Committee and the Committee of the Regions "Towards a common European data space", Brussels, 25 April 2018, SWD(2018) 125 final.

Farm Data Code. Edition 1. February 2020, https://nff.org.au/wp-content/uploads/2020/02/Farm_Data_Code_Edition_1_WEB_FINAL.pdf.

Farm Data Code of Practice. Version 1.1, http://www.farmdatacode.org.nz/wp-content/uploads/2016/03/Farm-Data-Code-of-Practice-Version-1.1_lowres_singles.pdf.

Hopkins M., ADAPT Conversion Toolkit Making In Roads With Equipment Manufacturers, 22 September 2016, https:// www.precisionag.com/digital-farming/data-management/adapt-conversion-toolkit-making-in-roads-with-equipment-manufacturers/.

Janzen T., The FieldView-Tillable Breakup: What Went Wrong, The Janzen Ag Tech Blog, 18 February 2020, https:// www.aglaw.us/janzenaglaw/2020/2/18/the-fieldview-tillable-breakup. 
Komunikat Komisji do Parlamentu Europejskiego, Rady, Europejskiego Komitetu Ekonomiczno-Społecznego i Komitetu Regionów, Europejska strategia w zakresie danych, COM(2020) 66 final, Bruksela, 19 lutego 2020 r. Micheletti G., Pepato C., Second Interim Report: The European Data Market Monitoring Tool: Key Facts \& Figures, First Policy Conclusions, Data Landscape and Quantified Stories, 28 June 2019, http://datalandscape.eu/sites/ default/files/report/D2.6_EDM_Second_Interim_Report_28.06.2019.pdf.

Precision farming. Trends and Outlook, AGRI MECH, June 2018, http://online.fliphtml5.com/zrio/dzoa/\#p=6.

Rozporządzenie Parlamentu Europejskiego i Rady (UE) 2016/679 z dnia 27 kwietnia 2016 r. w sprawie ochrony osób fizycznych w związku z przetwarzaniem danych osobowych i w sprawie swobodnego przepływu takich danych oraz uchylenia dyrektywy 95/46/WE (ogólne rozporządzenie o ochronie danych), Dz.Urz. UE L 2016.119.1.

Rozporządzenie Parlamentu Europejskiego i Rady (UE) 2018/1807 z dnia 14 listopada 2018 r. w sprawie ram swobodnego przepływu danych nieosobowych w Unii Europejskiej, Dz.Urz. UE L 2018.303.59.

Volume of data/information created worldwide from 2010 to 2024 (in zettabytes), Statista, https://www.statista.com/ statistics/871513/worldwide-data-created/. 